\title{
Język polski jako element tożsamości (na przykładzie wypowiedzi Polaków i Rosjan z obwodu kaliningradzkiego)
}

\section{KEYWORDS}

language, Polish language, language as an element of identity, Poles in Kaliningrad

\begin{abstract}
Kinga Kuszak, Katarzyna Sadowska, Język polski jako element tożsamości (na przykładzie wypowiedzi Polaków i Rosjan z obwodu kaliningradzkiego) [Polish language as an element of identity (on the example of statements by Poles and Russians from Kaliningrad Oblast)]. Kultura Społeczeństwo - Edukacja nr 2(18) 2020, Poznań 2020, pp. 115-127, Adam Mickiewicz University Press. ISSN 2300-0422. DOI 10.14746/kse.2020.18.5.1.

The article discusses the issue of Polish language as an element of identity of Poles and Russians living in Kaliningrad. The authors, during a visit to the University of Immanuel Kant, had the opportunity to do interviews with Poles and Russians living in Kaliningrad, for whom Polish is an important element of identity. The authors divided the respondents into two groups for whom Polish is an element of inherited identity and for whom Polish is an element of identity acquired in the education process. These analyzes precede reflections on the specifics and history of Kaliningrad and the kaliningrad district.
\end{abstract}

\section{Wprowadzenie}

Obwód kaliningradzki jest najdalej na zachód wysuniętym regionem Federacji Rosyjskiej. Jego specyfiką jest oddzielenie od reszty kraju granicami innych

* ORCID: 0000-0002-2430-7803.

** ORCID: 0000-0002-1255-0902. 
państw i wodami Morza Bałtyckiego. Od wschodu i północy obwód graniczy z Republiką Litewską, zaś od południa z Rzeczpospolitą Polską. Natomiast od zachodu znajduje się wybrzeże Morza Bałtyckiego. Obwód kaliningradzki to miejsce, gdzie Wschód spotyka się z Zachodem, a mieszkańcy mówią: "Już nie Rosja, a jeszcze nie Europa”. Mają poczucie odrębności od reszty Federacji Rosyjskiej (Palmowski, 2019b: 356). Od reszty kraju obwód kaliningradzki dzieli ponad $600 \mathrm{~km}$. Największym miastem tego obwodu jest Kaliningrad - miasto położone przy ujściu Pregoły do Morza Bałtyckiego. Koncentruje 46\% ludności i 60\% potencjału przemysłowego Federacji Rosyjskiej (Palmowski, 2019a: 109). Według danych z 2015 roku miasto liczyło 453,5 tys. mieszkańców. Aktualnie stanowi znaczące centrum administracyjne, przemysłowe, handlowe, naukowe oraz kulturalne regionu, a także największe centrum militarne. Pełni również funkcję ważnego ośrodka naukowego i akademickiego. Funkcjonują w nim 34 instytucje naukowe, w tym 6 szkół wyższych. Do najważniejszych należą: Rosyjski Państwowy Uniwersytet im. Immanuela Kanta, Państwowy Kaliningradzki Uniwersytet Techniczny, Bałtycka Akademia Państwowa, Instytut Prawniczy, Kaliningradzka Szkoła Wojenno-Morska, Kaliningradzki Instytut Pogranicza (Palmowski, 2019a: 111). Z kolei nieopodal położone miasta, jak Swietłogorsk, Zielonogradsk, Jantar, Pionersk, to nadbałtyckie miejsca rekreacyjne, wypoczynkowe i turystyczne. Obwód kaliningradzki w porównaniu z pozostałą częścią Rosji wyróżnia się silnie rozwiniętym sektorem małych przedsiębiorstw. Jak podaje Tadeusz Palmowski, jest ich dwukrotnie więcej niż w całej Rosji. Jest to efekt przywilejów, jakie przysługiwały regionowi od 2006 roku, które zezwalały na bezcłowy wwóz towarów na terytorium regionu, co niewątpliwie przyczyniło się do rozwoju handlu. T. Palmowski dodaje, że rozwój gospodarczy obwodu kaliningradzkiego jest efektem ożywionych kontaktów gospodarczych mieszkańców z sąsiadami (2019b: 356). Duże znaczenie dla rozwoju obwodu mają współpraca transgraniczna z Polską (odległość Kaliningradu od granicy Polski wynosi 35 km) i możliwość realizacji wspólnych projektów współfinansowanych ze środków Unii Europejskiej. Wśród dotychczasowych projektów, w których strona polska i kaliningradzka występowały w rolach beneficjentów, znalazły się te związane z budową oczyszczalni ścieków, budową dróg, ze współpracą w obszarze medycyny, kultury, sportu itp. (Palmowski, 2019b: 364). Jak zauważa T. Palmowski, „kontakty transgraniczne zainicjowały przełamywanie wzajemnych barier i uprzedzeń, tworzą stosunkowo nowe, formalne i nieformalne kontakty międzyludzkie pomiędzy społecznościami lokalnymi” (2019b: 364). 


\section{Kaliningrad - miasto wielu zmian, miasto wielu kultur. Zarys zagadnienia}

Kaliningrad jest miejscem, w którym wyraźnie widać wpływy niemieckie, rosyjskie i polskie. Jest regionem interesującym, o wyjątkowo skomplikowanej historii, pełnej zawirowań i zwrotów. To tygiel ludzi i kultur, które przez wieki się przeplatały i wzajemnie na siebie oddziaływały. To miasto, które od wieków w różnym stopniu powiązane jest z Polską.

Do czasów średniowiecza obszar dzisiejszego obwodu kaliningradzkiego „zamieszkiwali bałtyccy Prusowie, których następnie podbili Krzyżacy. W wyniku germanizacji oraz osadnictwa niemieckiego tereny te stały się obszarem zamieszkanym głównie przez ludność niemiecką. Niemniej jednak element polski odgrywał znaczącą rolę przez wiele stuleci, a język polski był obecny (wiele instytucji miejskich zatrudniało polskich tłumaczy, na Uniwersytecie Albertina był lektorat z języka polskiego, wydawano polskie książki i czasopisma)"1. W latach 1253-1257 zakon kawalerów mieczowych na zgliszczach osady pruskiej założył miasto (na cześć króla Czech Ottokara II z Bohemii) i odtąd Kaliningrad stanowił diecezję sambijską, która wchodziła w skład państwa krzyżackiego². Już w XV wieku Królewiec został włączony do Polski dzięki Kazimierzowi IV Jagiellończykowi. Województwo polskie ze stolicą w Królewcu przestało istnieć, gdy miasto zostało odbite przez wojska krzyżackie. W 1525 roku zostało stolicą Prus Książęcych zależnych od króla polskiego jako lenno. Królewiec wchodzący w skład Prus Książęcych stał się ich gospodarczą i intelektualną stolicą. Już w tym czasie stanowił swoisty „konglomerat różnych narodowości i wyznań”. Prusy były otwarte na wszelkie nowinki idące z Zachodu - z Niemiec, Polski, Holandii, Włoch. W roku 1757 Prusy Książęce znalazły się pod władaniem elektorów Brandenburgii, a cesarzowa Elżbieta Romanowa włączyła Królewiec do Cesarstwa Rosyjskiego. W rękach Rosjan pozostawał do 1763 roku. Po niemal kolejnych stu latach w 1871 roku Królewiec i cały obszar Prus Wschodnich włączono do Cesarstwa Niemieckiego proklamowanego w wersalskim pałacu. Pierwszym władcą nowo powstałego państwa był król pruski Wilhelm I3. W XX wieku, po zakończeniu II wojny światowej decyzją wielkich mocarstw podjętą podczas konferencji w Teheranie i potwierdzoną w Poczdamie Prusy Wschodnie zostały podzielone na dwie części: polską, obejmującą południową

\footnotetext{
1 Zob. https://kaliningrad.msz.gov.pl/pl [dostęp: 03.05.2019].

Zob. https://instytutintl.pl/pl/aktualnosci/item/403-historia-kalingradu [dostęp: 28.04.2019].

3 Zob. http://encyklopedia.warmia.mazury.pl [dostęp: 27.04.2019].
} 
część dawnych Prus Wschodnich, i północną część rosyjską, która przybrała po wojnie nazwę obwodu kaliningradzkiego. Tym samym w 1945 roku Armia Czerwona zajęła Prusy Wschodnie. Już rok późnej Królewiec otrzymał nową nazwę Kaliningrad - którą nadano miastu na cześć bolszewickiego komisarza Michaiła Kalinina (Siegień, 2016: 13). „Wkrótce po ustaleniu granic nowo powstałego obwodu kaliningradzkiego Stalin zdecydował, że stanie się on zamkniętym zmilitaryzowanym terytorium, gdzie będzie stacjonować radziecka Flota Bałtycka. W wyniku tej decyzji przez ok. 40 lat od końca wojny do Gorbaczowskiej pierestrojki Kaliningrad był niedostępny dla obcokrajowców, zwłaszcza z Zachodu” (Siegień, 2016: 13). Jednakże ze względu na silne zmilitaryzowanie dostęp do obwodu ograniczono także dla sowieckich obywateli. W wyniku tej sytuacji „powojenne losy miasta, które dla niemieckiej kultury stanowiło ważny symbol (w Königsbergu przecież Fryderyk I Pruski koronował się na króla Prus), przez dziesięciolecia pozostawały niezbadane. Izolacja pobudzała ciekawość i rozpalała wyobraźnię" (Siegień, 2016: 13). Można zatem stwierdzić, że do końca lat 80. obwód kaliningradzki (zarówno dla większości obywateli sowieckich, jak i dla pozostałej części Europy) stanowił swoiste tabu, był „najbardziej na zachód wysuniętą i silnie zmilitaryzowaną część RFSRR, oddzieloną od niej terytoriami republik wchodzących w skład jednego państwa federacyjnego” (Siegień, 2016: 13). Dopiero rozpad ZSRR odkrył przed światem zamknięty dotąd region. „Ostateczne wydzielenie obwodu ukształtowało się 8 grudnia 1991 r., gdy przestał istnieć ZSRR” (Siegień, 2016: 365). Jak zaznacza Andrzej Sakson, po upadku ZSRR „trudności polityczne związane z kształtowaniem się nowego państwa rosyjskiego i pogłębiający się kryzys w Rosji zrodziły liczne projekty dalszej przebudowy geopolitycznej obwodu kaliningradzkiego" (Sakson, 2011: 161). Wśród podawanych w prasie rosyjskiej propozycji dominowały te, które koncentrowały się na zwiększeniu samodzielności gospodarczej obwodu, przyznaniu regionowi autonomii, proponowano także przesiedlenie do obwodu „Niemców rosyjskich i przekształcenie go w Bałtycką Republikę Niemiecką w składzie Rosji” (Sakson, 2016: 161). Pojawiły się także realne plany dotyczące rozwoju obwodu kaliningradzkiego, które opracowali „miejscowi naukowcy razem z moskiewskimi i petersburskimi ekspertami” (Sakson, 2016: 162). Koncepcje te dotyczyły rozwoju obwodu jako regionu współpracy Federacji Rosyjskiej z Unią Europejską oraz wzmocnienia pozycji enklawy w gospodarce Rosji. U progu XXI wieku miało miejsce duże zainteresowanie gospodarczo-ekonomiczne obwodem kaliningradzkim. Region ten stał się m.in. specjalną strefą ekonomiczną, był także beneficjentem programu Federacji Rosyjskiej pt. „Rozwój obwodu kaliningradzkiego do 2010 r." oraz przyjętej w 2011 roku strategii rozwoju regionu na 25 lat (Sakson, 2016: 162). Skomplikowane dzieje miasta, szczególnie te najnowsze, które 
obejmowały całą Europę na przestrzeni XX i XXI wieku, odzwierciedlają się w historiach rodzin, $w$ indywidualnych biografiach jednostek. Pragniemy zatem spojrzeć na wybrane elementy ludzkich biografii przez pryzmat ich tożsamości kulturowej i językowej. W dalszych rozważaniach podejmiemy próbę spojrzenia na język jako element tożsamości kulturowej człowieka, a następnie, przez pryzmat wypowiedzi Polaków i Rosjan mieszkających w Kaliningradzie, spróbujemy opisać język polski jako element tożsamości odziedziczonej po poprzednich pokoleniach i nabytej w trakcie edukacji.

\section{Język jako element tożsamości kulturowej człowieka}

Nicolas Coupland pisze, że „język jest prawdopodobnie najmniej rozumianym przez ludzi wymiarem życia społecznego" (2001). Ludzie komunikują się z innymi za pomocą języka, lecz często nie rozumieją znaczeń, które za jego pomocą wyrażają lub które przekazują im inni ludzie. Zdaniem Edwarda Sapira „istotą rzeczy jest fakt, że prawdziwy świat jest w dużej mierze zbudowany nieświadomie na językowych nawykach grupy [...], widzimy, słyszymy, poznajemy w taki a nie inny sposób, gdyż przyzwyczajenia językowe naszej społeczności wysuwają pewien określony wzór interpretacji” (Zarzycki, 2014: 239). Przyjmując, że język jest elementem tożsamości jednostki, zakładamy, że tożsamość jest przez jednostkę konstruowana, jest podmiotowa, zaś język, którym się ona posługuje, uznaje za własny, choć niekoniecznie poddaje go refleksji w celu wyjaśnienia jego specyfiki. $\mathrm{Z}$ całą pewnością można jednak powiedzieć, że spotkanie jednostki z kulturą odbywa się za pośrednictwem języka, zaś „język nie istnieje w oderwaniu od kultury, tj. od społecznie dziedziczonego zbioru praktyk i wierzeń, które determinują materię naszego życia” (Sapir, 2010: 219). Jak podaje Dan I. Slobin, „treść mowy przekazuje normy, wartości i zgromadzoną wiedzę oraz obyczaje społeczności” (2007: 358). W ten sposób język staje się elementem poczucia tożsamości jednostki, ale zarazem jej poczucia wspólnotowości. Dzięki opanowaniu narzędzi językowych człowiek wchodzi do określonej wspólnoty. Dziecko, zanurzając się w określonym języku, uczy się mówić jak użytkownik tego języka: hiszpańskiego, angielskiego, polskiego, rosyjskiego, uczy się jednocześnie tego, jak „opowiadać, prowadzić wywód, stawiać żądanie” (Slobin, 2007: 365). Po prostu zaczyna się posługiwać określonym językiem w naturalny sposób, uznaje go za użyteczne narzędzie komunikacji z innymi ludźmi, którzy tworzą określoną wspólnotę. Oprócz ogólnych prawidłowości związanych z opanowywaniem języka prowadzącego do osiągnięcia statutu dojrzałego użytkownika języka można dostrzec specyfikę prowadzącą do 
uzyskania przez jednostkę statusu użytkownika określonego języka. Paul Ricoeur dodaje, że kluczową rolę w kształtowaniu poczucia własnej tożsamości jednostki i grupy odgrywa właśnie język i narracja językowa. Nie bez przyczyny językoznawcy, psycholodzy, socjolodzy, antropolodzy używają pojęcia „speech community”mówiąca społeczność, którą charakteryzuje się poprzez wspólny język i praktyki z nim związane dające się zaobserwować podczas różnych codziennych, prywatnych i profesjonalnych, sytuacji (Rampton, 2000: 101). Uczeń Sapira Benjamin Lee Whorf dodaje, że język, którym się posługujemy, wpływa na nasz sposób myślenia o świecie. Z tego założenia wynika, że „mówiąca społeczność” w podobny sposób myśli o otaczającym ją świecie. Dowodzą tego badania z udziałem przedstawicieli plemienia Piraha - niewielkiej rdzennej społeczności zamieszkującej Brazylię. Naukowcy odkryli, że w języku tego plemienia nie ma pewnych kategorii słów, szczególnie liczebników, co wpływa na myślenie i funkcjonowanie tych osób, które nie posługują się liczebnikami, ale przecież potrafią liczyć. Aby sprawnie funkcjonować, korzystają z trzech określeń: „jeden”, „dwa” i „dużo”. Zdaniem Daniela L. Everetta jest to dowód na to, że w plemieniu Piraha brak liczebników wynika z kulturowego tabu zakazującego zbędnych uogólnień wykraczających poza „tu i teraz” (Everett, 2018: 345-349). Wspomniany autor pisze dalej: „Ludzie często reagują z niedowierzaniem: Chcesz powiedzieć, że matka w plemieniu Piraha nie wie, ile ma dzieci? Zgadza się - żadna kobieta $\mathrm{z}$ tego plemienia nie potrafiłaby powiedzieć, czy ma jedno, troje czy sześcioro dzieci. Z pewnością jednak bez trudu wymieni imiona ich wszystkich i będzie dokładnie wiedziała, gdzie znajduje się każde z ich, czy jest bezpieczne, zdrowe i tak dalej” (Everett, 2018: 350). Reprezentantom kultury Zachodu trudno to zrozumieć, tym bardziej że od najmłodszych lat wpaja im się, że matematyka jest podstawą funkcjonowania jednostki w nowoczesnym świecie. Trudno zatem nie zgodzić się z tezą Edwarda Sapira, że „formy każdego języka ustalają określone poczucie ustosunkowania lub postawę wobec wszelkich możliwych treści wyrażania, a za ich pośrednictwem - wobec wszelkich możliwych treści doświadczenia, oczywiście w stopniu, w jakim doświadczenie może być wyrażane językowo" (Slobin 2007: 361). Warto zatem zaznaczyć, że również różnice między językami zachodniego kręgu kulturowego determinują doświadczenia jednostek, a tym samym kształtują ich poczucie tożsamości. Jak bowiem zaznacza Dan I. Slobin, „każdy język wymaga automatycznego i systematycznego wykorzystania przez użytkownika zestawu rozróżnień semantycznych, które nie są bezpośrednio dane w codziennej percepcji i w działaniu czy wymuszone wymogami życia praktycznego" (2007: 362). Wspomniany autor pisze dalej, że człowiek uczy się za pomocą narzędzi językowych, które „są jedynymi środkami wskazania odpowiednich kategorii zdarzeń" (2007: 362), a te narzędzia są 
różne w różnych językach. Kultura bowiem różnicuje ludzi, nawet jeżeli zadania, aktywności, role, które podejmują, są (czy wydają się) uniwersalne. Te rozważania stanowią punkt wyjścia do podjęcia wątków związanych z poczuciem tożsamości wspólnotowej mieszkańców obwodu kaliningradzkiego - regionu, w którym historyczne przemiany społeczne, kulturowe, ekonomiczne itp. determinowały losy jednostek i całych grup społecznych pierwotnie wywodzących się z różnych kręgów językowych oraz kulturowych. Przedmiotem naszych zainteresowań będzie język polski jako element tożsamości odziedziczonej i wybranej.

\section{Język polski jako element tożsamości odziedziczonej na przykładzie mieszkańców Kaliningradu}

Współcześni Polacy mieszkający w obwodzie kaliningradzkim stanowią grupę liczącą 3,9 tys. osób (Żęgota, 2002). Krzysztof Żęgota zwraca uwagę na to, że liczba Polaków jest z całą pewnością większa od tej ujętej w statystykach, ponieważ część mniejszości etnicznych w każdym kraju przyznaje się do narodowości reprezentowanej przez większość, a więc nie przyznaje się do narodowości odziedziczonej po przodkach. Drugą z przyczyn jest fakt, że „w czasach Związku Radzieckiego głoszono indyferentyzm narodowy jako oficjalną ideologię państwową, zastępując poczucie przynależności narodowej wzorem sowietskogo czełowieka, stanowiącą swego rodzaju wygodny substytut jednoznacznych deklaracji narodowościowych" (Żęgota, 2002: 268). Teoria ta, jak dodaje Swietłana Czerwonnaja, „wyrażała realne procesy silnej integracji, w wyniku której formułowało się wielkie skupisko ludzi pozbawionych pamięci historycznej i niemających głębokich związków ze źródłami, korzeniami, tradycjami własnej kultury narodowej, z religią swoich ojców" (1997: 121). Przynależność do Związku Radzieckiego była silniejsza od przynależności narodowej. K. Żęgota zwraca uwagę na to, że by określić liczbę Polaków mieszkających aktualnie w obwodzie kaliningradzkim, należy przeanalizować proces przesiedlania do obwodu ludności z innych obszarów Związku Radzieckiego (2002: 268). Największa grupa Polaków to przesiedleńcy z Kazachstanu, z Syberii, Mołdawii, Białorusi i Kirgistanu. Te fakty odnajdujemy również w wynikach naszych badań. Badania zostały przeprowadzone metodą jakościową, a gromadzenie danych miało formę pogłębionych wywiadów indywidualnych. Materiał badawczy pozyskano podczas pobytu związanego z obchodami Dnia Języka Polskiego zorganizowanymi przez Wydział Humanistyczny Bałtyckiego Uniwersytetu Federalnego im. Immanuela Kanta w dniach 23.03-30.03.2019. Indywidualne gromadzenie materiału pozwoliło pozyskać wiedzę na temat doświadczeń rodzin- 
nych i osobistych uczestniczek, subiektywnych interpretacji tych doświadczeń i zdarzeń, w których uczestniczyły ich rodziny i one same. Osoby uczestniczące w badaniu, opisując swoje rodzinne historie, zwracały uwagę na trudne i skomplikowane losy rodziców i dziadków w następujący sposób: „Babcia przyjechała z Litwy do Kaliningradu w 1957 roku. Przyjechała z Wilna w poszukiwaniu pracy i lepszych warunków do życia po wojnie”; „Ojciec miał pracę wojskową, w czasach Związku Radzieckiego moja rodzina przyjechała z Białorusi”; „Moja rodzina przyjechała $\mathrm{z}$ miejscowości Wilejka - miasto na Białorusi, w obwodzie mińskim”; „Pochodzimy z byłych terenów Rzeczpospolitej Polskiej - obecnie jest to teren Białorusi”; „Przyjechaliśmy z Kazachstanu, chcieliśmy być jak najbliżej Polski”; „W 1962 roku moja rodzina przyjechała z Wilna”. Zgromadzone przez nas wypowiedzi odzwierciedlają zjawisko przemieszczania się ludności polskiego pochodzenia z głębi Związku Radzieckiego w kierunku granicy z Polską. Ta część Polaków to również, jak podają statystyki, najliczniejsza grupa posiadaczy Karty Polaka (Górny, Kindler, 2008: 226). Współcześni Polacy mieszkający w obwodzie kaliningradzkim są niejednokrotnie potomkami represjonowanych przed laty mieszkańców naszego kraju, pozbawionych korzeni, tożsamości i języka. Zatem niełatwe pokoleniowe doświadczenia determinują to, w jaki sposób współcześni Polacy mieszkający w Kaliningradzie werbalizują swoją tożsamość. Część z nich określa siebie jako Polki i Polaków, np. „Jestem Polką, w mojej rodzinie podtrzymuję polskie tradycje”. Inni mówią tak (dwie respondentki); „Jestem Rosjanką oraz Polką”; „Reprezentuję połączenie kultury polskiej i rosyjskiej”. Jeszcze inni definiują swoją tożsamość w następujący sposób: „Jestem człowiekiem świata”. Józef Byczkowski, dokonując analizy sytuacji językowej Polaków na terenie ZSSR, dostrzega, że w 1959 roku językiem polskim posługiwało się 45,2\% ogółu Polaków, w 1970 roku język polski jako język ojczysty wskazało 32,5\% Polaków, a w 1979 tylko 29,1\% (1990: 137-138). Ta sytuacja historyczna może być uzasadnieniem dla uzyskanych przez nas odpowiedzi na temat tożsamości narodowej części osób badanych. Pytani przez nas mieszkańcy obwodu kaliningradzkiego o to, w jakim języku komunikują się z najbliższymi, odpowiedzieli: „Rosyjskim”; „Rosyjskim, rzadko polskim”; „Niestety po rosyjsku, ale chcemy się uczyć polskiego”; „Po polsku i po rosyjsku”. Tak sytuację opisuje jedna z naszych rozmówczyń: „Polonia kaliningradzka to przede wszystkim osoby, które nauczyły się (lepiej lub gorzej) polskiego już jako osoby dorosłe. Mimo poczucia wspólnoty z Polską, polskimi tradycjami itp. język polski dla nich jest językiem obcym. Chcą jednak, żeby ich dzieci nauczyły się polskiego". Politykę edukacyjną Federacji Rosyjskiej kształtują wcześniejsze doświadczenia asymilacyjne wobec ludności przesiedlanej, stąd, jak podkreślają nasze rozmówczynie, „w Kaliningradzie nie ma polskich szkół. Są 
szkoły (mało), w których uczniowie mogą wybrać język polski jako np. drugi lub nawet trzeci język obcy po angielskim i/albo niemieckim. Najczęściej to są dzieci, które nie mają polskiego pochodzenia. Po prostu rodzice uważają, że warto uczyć się języka sąsiadów”. W rezultacie najmłodsze pokolenie nie mówi po polsku lub mówi bardzo słabo, niemal wyłącznie w gronie najbliższych.

Polacy mieszający na terytorium obwodu kaliningradzkiego korzystają jednak z prawa do utrzymywania tożsamości narodowej oraz kulturowej i zrzeszają się w niezależnych organizacjach polonijnych. W chwili obecnej istnieje ich dziesięć, a wśród nich trzy największe. Są to:

- Autonomia Polaków w Kaliningradzie „Polonia”,

- Stowarzyszenie „Dom Polski” im. Fryderyka Chopina w Czerniachowsku,

- Wspólnota Kultury Polskiej im. Jana Kochanowskiego w Oziersku.

Ponadto w regionie funkcjonują następujące wspólnoty i stowarzyszenia:

- Wspólnota Kultury Polskiej w Bałtijsku,

- Stowarzyszenie Inicjatyw Polonijnych w Kaliningradzie,

- Wspólnota Kultury Polskiej w Gusiewie,

- Polesska Rejonowa Organizacja Społeczna „Stowarzyszenie Kultury Polskiej Królowa Jadwiga",

- Wspólnota Kultury Polskiej w Znamiensku,

- stowarzyszenie polonijne Związek Młodzieży „Polonez”,

- stowarzyszenie polonijne Królewiczanie.

Dwa spośród nich (Autonomia Polaków w Kaliningradzie „Polonia”, „Dom Polski” w Czerniachowsku) mają uprawnienia do wystawiania zaświadczeń potwierdzających aktywne zaangażowanie w działalność na rzecz utrzymania języka i kultury polskiej. Mają też uprawnienia do wystawiana Karty Polaka.

Ważnymi instytucjami podtrzymującymi kulturę i język polski w obwodzie kaliningradzkim są parafie katolickie, których w rejonie jest około 20, w tym dwie funkcjonują w samym Kaliningradzie. Poprzez typowo polskie obrzędy sprzyjają utrzymaniu poczucia tożsamości narodowej i przynależności do kraju, na co wskazują wypowiedzi: „Tak jak w Polsce dzielimy się jajkiem, święcimy koszyczek”; „Na Boże Narodzenie śpiewamy kolędy, dzielimy się opłatkiem, na Wielkanoc robimy palmy i pisanki”; „Malowanie jajek, wielkanocne ciasto”; „Opłatek, spotkania wigilijne, śpiewanie polskich kolęd”; „Na wigilię mamy dwanaście dań, tak jak w Polsce”; „Staramy się chodzić co tydzień do kościoła i jeździć na pielgrzymki”.

Interesującą inicjatywę związaną z utrzymywaniem języka i kultury polskiej opisuje jedna z uczestniczek naszych wywiadów: „Ostatnio pojawił się pomysł, który jest co prawda w tej chwili w stanie kiełkującym, założenia klubu, do którego mogłyby przychodzić matki z dziećmi i tam bawić się razem i rozmawiać po pol- 
sku. Te matki to absolwentki naszej polonistyki, które chciałyby, żeby ktoś nauczył ich dzieci polskiego. Ponieważ nie ma takich zajęć w naszym mieście, to zastanawiają się nad tym, żeby zorganizować takie spotkania we własnym zakresie”. To przykład troski o to, by język, tradycję, kulturę i poczucie tożsamości narodowej przekazywać najmłodszemu pokoleniu Polaków.

\section{Język polski jako element tożsamości wybranej - na przykładzie mieszkańców Kaliningradu}

Obwód kaliningradzki to region, w którym ze względu na bliskość z Polską zaobserwować można duże zainteresowanie naszym krajem, językiem i kulturą. Na Uniwersytecie Federalnym im. Immanuela Kanta na Wydziale Humanistycznym studenci mają możliwość studiowania języka polskiego. Z tej możliwości korzystają. Motywy tej decyzji są różne. „Ucząc się w szkole, byłam zafascynowana językiem angielskim. Chciałam zostać nauczycielką angielskiego. Ale niestety nie dostałam się na anglistykę z różnych przyczyn i wtedy poradzono mi zwrócić uwagę na nową specjalność - polonistykę. Nie wiedziałam, że w ogóle istnieje. Zgodziłam się i nie żałowałam ani przez chwilę" - mówi jedna z absolwentek Wydziału (W 1). Inna dodaje: „Moja przygoda z językiem polskim zaczęła się bardzo dawno, kiedy miałam 10 lat. Pierwszy raz z mamą pojechałyśmy do Polski na wycieczkę, potem kupiłyśmy podręcznik do języka polskiego i stał on na półce, póki w mojej szkole nie pojawiły się dodatkowe zajęcia $\mathrm{z}$ języka polskiego. W dziewiątej klasie zaczęło tam chodzić 25 osób, a w jedenastej było nas czworo. Dowiedziałam się, że mamy wydział polonistyki na uniwersytecie i zdecydowałam: czemu nie? Nie miałam ani korzeni polskich, ani znajomych tam, a jednak miałam zamiłowanie do tej kultury, łatwo mi było uczyć się polskich słówek na pamięć" (W 2).

Studia polonistyczne były (są) okazją do poznawania nie tylko języka, ale także kultury polskiej: „W latach 2004-2009 byłam pilną studentką polonistyki. To chyba były najlepsze lata mojego życia. Ciągle podróżowaliśmy po Polsce, szkoły letnie, praktyki, konkursy recytatorskie w konsulacie, artykuły dla gazety polonijnej... Właśnie o tym mój hymn. Dużo wszystkiego można opowiedzieć...” (W 2). Inna z naszych rozmówczyń tak opisuje swoją decyzję związaną z wyborem polonistyki: „Pod koniec liceum postanowiłam, że chciałabym pójść na studia filologiczne, jednak na początku myślałam o filologii rosyjskiej. Postanowiłam porozmawiać o tym ze starszą koleżanką, która wtedy właśnie kończyła rusycystykę na naszym Uniwersytecie Kanta (który wówczas jeszcze wcale się tak nie nazywał). Ona powiedziała mi, że na Wydziale Filologii Słowiańskiej pojawił się kierunek poloni- 
styka i poradziła mi spróbować swoich sił na tym właśnie kierunku. W ten oto sposób wybrałam swoją drogę życiową" (W 8). Absolwentki polonistyki podzieliły się z nami swoimi odkryciami związanymi z językiem polskim. Jedna z nich opowiedziała o spotkaniu z literaturą poznańskiej pisarki Małgorzaty Musierowicz: „Na pierwszym roku studiów pojechałam wraz z rodzicami do Gdańska, żeby odwiedzić ich polskich przyjaciół z lat młodości, z którymi się nie widzieli ponad 15 lat. Wtedy mogłam już mówić po polsku (w miarę szybko, choć z błędami). Pani Renata, przyjaciółka moich rodziców, zaproponowała mi zabrać do domu 3 książki nieznanej mi wtedy Małgorzaty Musierowicz i oddać przy kolejnym spotkaniu. $\mathrm{Z}$ wyglądu nieszczególnie mnie zainteresowały (chyba przez te trochę dziecinne obrazki na okładkach), ale podziękowałam i wzięłam je. Później sięgnęłam po jedną z nich - pamiętam, że była to Noelka - i zaczęłam czytać. «Noelka była mocna i zdrowa jak orzech». Piszę to pierwsze zdanie z pamięci. Czytałam i nie mogłam się oderwać. Połknęłam te 3 książki w tempie ekspresowym, a potem to już zaczęłam zbierać swoją biblioteczkę Jeżycjady. Teraz mam wszystkie książki pani Musierowicz. Niektóre z nich znam prawie na pamięć. Zawsze towarzyszyły mi w trudniejszych chwilach mojego życia. No i jestem pewna, że ta właśnie pasja pomogła mi w nauce języka polskiego, natomiast bogactwo języka, którym posługuje się autorka, pomogło mi kilkakrotnie zwyciężyć w konkursie "Polskie dyktando»" (W 8). To przykład tego, w jaki sposób kręgi społeczne, w których funkcjonują jednostki, determinują ich zainteresowania, w tym również zainteresowania językowe, a tym samym przyczyniają się do wrastania w określoną kulturę.

Wypowiedzi kolejnych uczestniczek naszego badania wskazują, że poznawanie i zgłębianie języka polskiego wiąże się z osobistą satysfakcją, niesie też wymierne korzyści dla rozwoju zawodowego: „Wiele osób chce się uczyć języka polskiego, ponieważ często wyjeżdżają na zakupy do Polski, mogą rozwijać kontakty biznesowe z Polską" (W 3). Te wypowiedzi pozwalają zrozumieć zainteresowanie polonistyką jako kierunkiem studiów. Zalety związane z posługiwaniem się językiem polskim wymienia też kolejna uczestniczka naszego wywiadu, wskazuje, że „w Kaliningradzie zainteresowanie językiem polskim podwyższa się z powodu naszego sąsiedzkiego położenia" (W 4). Podczas rozmów badani zwracali uwagę na duże zainteresowanie kulturą polską szczególnie w szkołach (W 5) oraz kultywowanie polskich tradycji, np. bożonarodzeniowych: „Śpiewamy kolędy po polsku” (W 6); „Stawiamy szopkę, słuchamy kolęd i współczesnych piosenek w języku polskim, czytamy fragmenty Biblii po polsku" (W 7).

Nasze rozmówczynie dzieliły się z nami swoją autentyczną pasję, jaką jest język polski, a także praca z nim związana: „Po studiach poszłam uczyć polskiego i od tej pory tym się zajmuję na co dzień. Moja praca jest też moją pasją" (W 8). 
Absolwentki polonistyki czują się spełnione, z perspektywami rozwoju zawodowego: „Żadnego razu nie żałowałam, że związałam swoje życie z językiem polskim. Zawsze praca mnie szuka, a nie ja jej. Już od 10 lat uczę polskiego. Pracuję w szkole językowej Ekspert w Kaliningradzie. Teraz jestem na urlopie macierzyńskim, synek ma 14 miesięcy, ale już pracuję po troszeczku" (W 1). Praca jest dla wielu z nich istotnym elementem stylu życia. Wskazywały, że zarówno w pracy zawodowej, jak i życiu prywatnym pragną rozbudzić zainteresowanie językiem polskim. Co ciekawe, jedna z naszych rozmówczyń wychowuje swoje dziecko, komunikując się z nim wyłącznie w języku polskim: „Zaczęłam uczyć polskiego moje dziecko, bo chciałam przekazać swoją wiedzę i miłość do języka i kraju. W związku z położeniem Kaliningradu dość często (w każdym razie znacznie częściej niż gdziekolwiek) wyjeżdżamy do Polski, więc znajomość języka na pewno nie zaszkodzi. Prócz tego, kiedy studiowałam nauczanie polskiego jako obcego na Uniwersytecie Jagiellońskim, dużo słyszałam i czytałam o dzieciach dwujęzycznych i bardzo mnie to zainteresowało. Był to pewnego rodzaju eksperyment, czy to naprawdę działa tak, jak o tym piszą. W Rosji matki mogą przebywać na urlopie macierzyńskim 3 lata. Jest to dość długi okres, aby, nie używając języka, stracić nawyki. Dlatego też zaczęłam rozmawiać $\mathrm{z}$ córką, aby nie zapomnieć języka i podtrzymać go na przyzwoitym poziomie. Czytamy książki, które kupuję w Polsce, oglądamy bajki po polsku i słuchamy piosenek i audiobooków" (W 2). To zatem przykład na to, w jaki sposób mieszkańcy Kaliningradu wybierają dla siebie i swoich dzieci język, który staje się częścią ich tożsamości i kultury.

\section{Zakończenie}

Niełatwe i skomplikowane osobiste historie współczesnych Polaków i Rosjan mieszkających w obwodzie kaliningradzkim (i ich przodków) z całą pewnością wymagają pogłębionych poszukiwań i dalszych analiz. Niniejsze opracowanie stanowi jedynie szkic do dalszych prac badawczych. Naszym zamierzeniem było zwrócenie uwagi na to, że jednostki poprzez doświadczenia wcześniejszych pokoleń ( $w$ formie przekazów ustnych i pozostawionych dokumentów), ale także własne - najbardziej aktualne - określają swoje poczucie przynależności do grupy językowej. Definiują język polski jako ten, który determinuje indywidualną tożsamość. Biorąc pod uwage historyczną specyfikę obwodu kaliningradzkiego - swoistego tygla kultur, języków, przesuwanych granic i przemieszczanych grup narodowościowych oraz aktualnej bliskości przygranicznej - określenie Ludwiga Wittgensteina, że „granice mojego języka są granicami mojego świata", nabiera innego znaczenia. 


\section{Bibliografia}

Achremczyk S. (2005), Olsztyńskie badania dziejów Królewca i Kaliningradu po 1945 roku, „Komunikaty Mazursko-Warmińskie", nr 3.

Byczkowski J. (1990), Polonia w Europie, Opole.

Coupland N. (2001), Introduction: Sociolinguistic Theory and Social Theory, w: Sociolinguistics and Social Theory, eds. N. Coupland. S. Srangi, Ch.N. Candlin, London.

Czerwonnaja S. (1997), Wieloetniczny kompleks współczesnej kultury rosyjskiej: dialog czy konfrontacja religii, narodów, państw, w: Dylematy tożsamości europejskich pod koniec drugiego tysiąclecia, red. J. Mucha, W. Olszewski, Toruń.

Everett D.L. (2018), Język. Narzędzie kultury, Kraków.

Górny A., Kindler M. (2008), Cudzoziemcy w Polsce na przełomie XX i XXI wieku, w: 25 wykładów o migracjach, red. M. Lesińska, M. Okólski, Warszawa.

Palmowski T. (2019a), Nowe modele wspótpracy Gdańska i Kaliningradu, https://depot.ceon.pl [dostęp: 11.04.2019].

Palmowski T. (2019b), Obwód kaliningradzki i jego współczesne dylematy, www.journals.pan.pl [dostęp: 11.04.2019].

Rampton B. (2000), Continuity and Change in Views of Society in Applied Linguistics, „Urban Language \& Literacies".

Sakson A. (2011), Geostrategiczne aspekty „problemu kaliningradzkiego”, „Przegląd Strategiczny”, nr 2.

Sapir E. (2010), Język. Wprowadzenie do badań nad mową, Kraków.

Sidorkiewicz R. (2019), Dziedzictwo historyczne współczesnego Kaliningradu, http://akant.org/ archiwum/219-swiat-inflant/swiat-inflant-2018/swiat-inflant-2018-nr-1/6558-roman-sidorkiewicz-dziedzictwo-historyczne-wspolczesnego-kaliningradu-1 [dostęp: 22.04.2019].

Siegień P. (2016), Königsberg i Kaliningrad - między pamięcią, utratą i zapomnieniem, „Problemy Rozwoju Miast", r. XIII, z. II.

Sikorski J., Jasiński J. (2014), Mikołaj Kopernik, Immanuel Kant. Dwie najwybitniejsze postacie nauki na ziemiach niegdyś pruskich, Olsztyn.

Slobin D.I. (2007), Od użytkownika języka dziecięcego do użytkownika języka ojczystego, w: Psychologia języka dziecka. Osiagnięcia, nowe perspektywy, red. B. Bokus, G.W. Shugar, Gdańsk.

Zarzycki Ł. (2014), O językowej tożsamości człowieka w kontekście dyskursu religijnego, „Studia Językoznawcze", nr 5.

Żęgota K. (2002), Liczebność diaspory polskiej w obwodzie kaliningradzkim Federacji Rosyjskiej. Zarys problematyki, „Środkowoeuropejskie Studia Polityczne”, nr 1 (12).

\section{Netografia}

http://encyklopedia.warmia.mazury.pl/index.php/Kr\%C3\%B3lewiec [dostęp: 27.04.2019]

https://instytutintl.pl/pl/aktualnosci/item/403-historia-kalingradu [dostęp: 28.04.2019]

https://kaliningrad.msz.gov.pl/pl/informacje_konsularne/opieka_konsularna/polak_w_ok/ polak_w_ok [dostęp: 03.05.2019] 
